\title{
Preliminary data on carbon production of deep-sea vent tubeworms
}

\author{
B. Shillito ${ }^{1, *}$, J. Ravaux ${ }^{1}$, F. Gaill ${ }^{1}$, J. Delachambre ${ }^{2}$, E. Thiébaut ${ }^{3}$, J. J. Childress ${ }^{4}$ \\ ${ }^{1}$ INSU UPR 9042 CNRS Roscoff, UPMC, 7 Quai Saint Bernard, F-75252 Paris, France \\ ${ }^{2}$ UMR 5548 CNRS, University of Dijon, 6, Bd Gabriel, F-21000 Dijon, France \\ ${ }^{3}$ ESA 7076 CNRS, UPMC, 7 Quai Saint Bernard, F-75252 Paris, France \\ ${ }^{4}$ Department of Biological Sciences, Marine Science Institute, University of California, Santa Barbara, California 93106, USA
}

\begin{abstract}
The deep-sea tubeworm Riftia pachyptila and its endosymbiotic bacteria are thought to be major primary producers of the East Pacific Rise hydrothermal vent ecosystem. Tube production rates were measured for worms maintained alive in pressure aquaria. These rates $(y)$ correlate to the fresh weight $(x)$ of individuals, following an almost square-root relationship $\left(y=0.192 x^{0.492}\right)$. Extrapolation of experimental data to in situ animal densities (in dense clumps) leads to rates that may exceed $1 \mathrm{~g} \mathrm{C} \mathrm{m}^{-2} \mathrm{~d}^{-1}$ for worms from the Parigo site $\left(13^{\circ} \mathrm{N}\right)$. Thus, vestimentiferan tube growth alone would indicate that this vent site is a remarkable benthic hotspot for carbon production. Finally, it seems that these rates differ depending on the in situ origin of the animals, thus suggesting that in the future this type of experiment may provide quantitative information concerning the vitality of different vent sites.
\end{abstract}

KEY WORDS: Riftia pachyptila - Tube - Hydrothermal vents . Carbon production

It is commonly believed that hydrothermal vents are the site of intensive organic carbon production, mainly due to chemosynthetic bacterial primary production (Tunnicliffe 1991, Vetter 1994, Van Dover 1995). In particular, endosymbiotic associations, such as those occurring in the case of the giant vestimentiferan Riftia pachyptila (Childress \& Fisher 1992, Gardiner \& Jones 1993), are thought to be a major source of organic matter for higher level consumers. However, such carbon transfer pathways are difficult to quantify at deep-sea vents, where access is difficult and limited in time. In situ observations, or videoscopic studies, have allowed quantification of the overall growth of the endosymbiotic hosts for some slow-growing cold-seep vestimentiferans (Fisher et al. 1996), and also for Riftia

•E-mail: bruce.shillito@snv.jussieu.fr pachyptila, with impressive reports of $85 \mathrm{~cm} \mathrm{yr}^{-1}$ of tube growth (Lutz et al. 1994). Tube growth is interesting to evaluate, in that it is a part of the host-symbiont system that definitely belongs to the host, thus reflecting transfer of organic matter from symbionts to host. Furthermore, it can be readily observed in situ (Roux et al. 1989, Lutz et al. 1994). However, tube elongation does not seem to be a good measure of tube growth. Indeed, previous observations concerning the process of tube growth of $R$. pachyptila show that many individuals may grow by producing basal lateral extensions to their tube (Gaill et al. 1997), suggesting that a $1.5 \mathrm{~m}$ long tube (as observed by Lutz et al. 1994) could correspond to a higher total length grown, if these extensions were considered.

The approach in this work consists of measuring accurately total tube production of worms maintained alive in pressurized aquaria. Placing the worms in artificial tubes, prior to the re-pressurization, allows us to later collect entirely and unambiguously the fresh tube material that was produced during the experiment. Moreover, such production is measurable after dailyscale experimental durations, and therefore reflects a process which is close to gross tube production, whereas tube incrementation observed in situ on large time scales is most probably the result of tube synthesis and tube decay or consumption, and therefore would rather reflect net production.

Material and methods. Animal collection: Tubeworms were collected with the submersible 'Nautile' (IFREMER), during the 'HOT 96' cruise, at $12^{\circ} 48^{\prime} \mathrm{N}$, $103^{\circ} 56^{\prime} \mathrm{W}$, at $2640 \mathrm{~m}$ depth (Genesis and Parigo sites), or $9^{\circ} 50^{\prime} \mathrm{N} ; 104^{\circ} 17^{\prime} \mathrm{W}$, at $2530 \mathrm{~m}$ depth (Riftia Field and Q-Vent sites). During submersible ascent, they were maintained in a heat-insulated container and were subject to a decompression of about 260 bars within $1 \mathrm{~h}$. 
Pressure experiments: Prior to re-pressurization, the tubeworms were withdrawn from their native tubes and wrapped in a polyethylene sheet (i.e. an artificial tube) that was fastened around them. The steel vessels on board allowed us to maintain a pressure of 210 bars with a constant flow-through of chemically modified surface seawater, at $15^{\circ} \mathrm{C}$. The chemical compositions in the aquaria were checked daily (min.-max. values: $\Sigma \mathrm{H}_{2} \mathrm{~S}=150$ to $270 \mu \mathrm{M} ; \Sigma \mathrm{CO}_{2}=1760$ to $3320 \mu \mathrm{M} ; \mathrm{pH}=6.1$ to 6.9$)$ and were similar to vent conditions. The duration of the experiments ranged from $3 \mathrm{~h}$ to $3 \mathrm{~d}$. For quantification experiments (see Fig. 2), worms were selected only if they had not undergone decompression events during the experimental period. Other individuals (decompressed during experiments) were used to illustrate qualitatively tube deposition (See Fig. 1). At the end of the experiments, worms that appeared damaged or remained motionless upon mechanical stimulation were disregarded, even if they had produced tube material. Healthy individuals were separated from their tubes, weighed again $( \pm 3 \mathrm{mg}$ error) (Childress \& Mickel 1980), and measured. Fresh tube material deposits were scraped off the paper and stored in liquid nitrogen. Back onshore, these samples were lyophylized, weighed ( $\pm 1 \mathrm{mg}$ error), and further stored at $-80^{\circ} \mathrm{C}$ in sealed tubes.

Carbon content analysis: Previous studies have shown that the tube composition of Riftia pachyptila is essentially organic ( $3 \%$ ash) (Gaill \& Hunt 1986). Carbon content was determined for fresh tube secretions of 4 different worms. Two replicates of secretions from each tube of 3 of the worms were subject to an analysis of total carbon and nitrogen content with a Nitrogen Analyser 1500 (Carlo Erba Strumentazione, $1 \%$ measurement error) (minimum weight of sample required for this analysis is $500 \mu \mathrm{g}$ ). For the other worm, which had produced a $30 \mathrm{~cm}$ long tube secretion, the material was divided into 5 equivalent parts along the tube length, and each of these parts was duplicated. Therefore, 16 measurements were made, yielding an average carbon content as \% of dry weight of the sample, \pm SD.

Results. Out of the total 22 tubeworms that were studied, less than $10 \%$ (2) showed no detectable fresh tube secretion on the surface of the artificial tube, and tube produc-
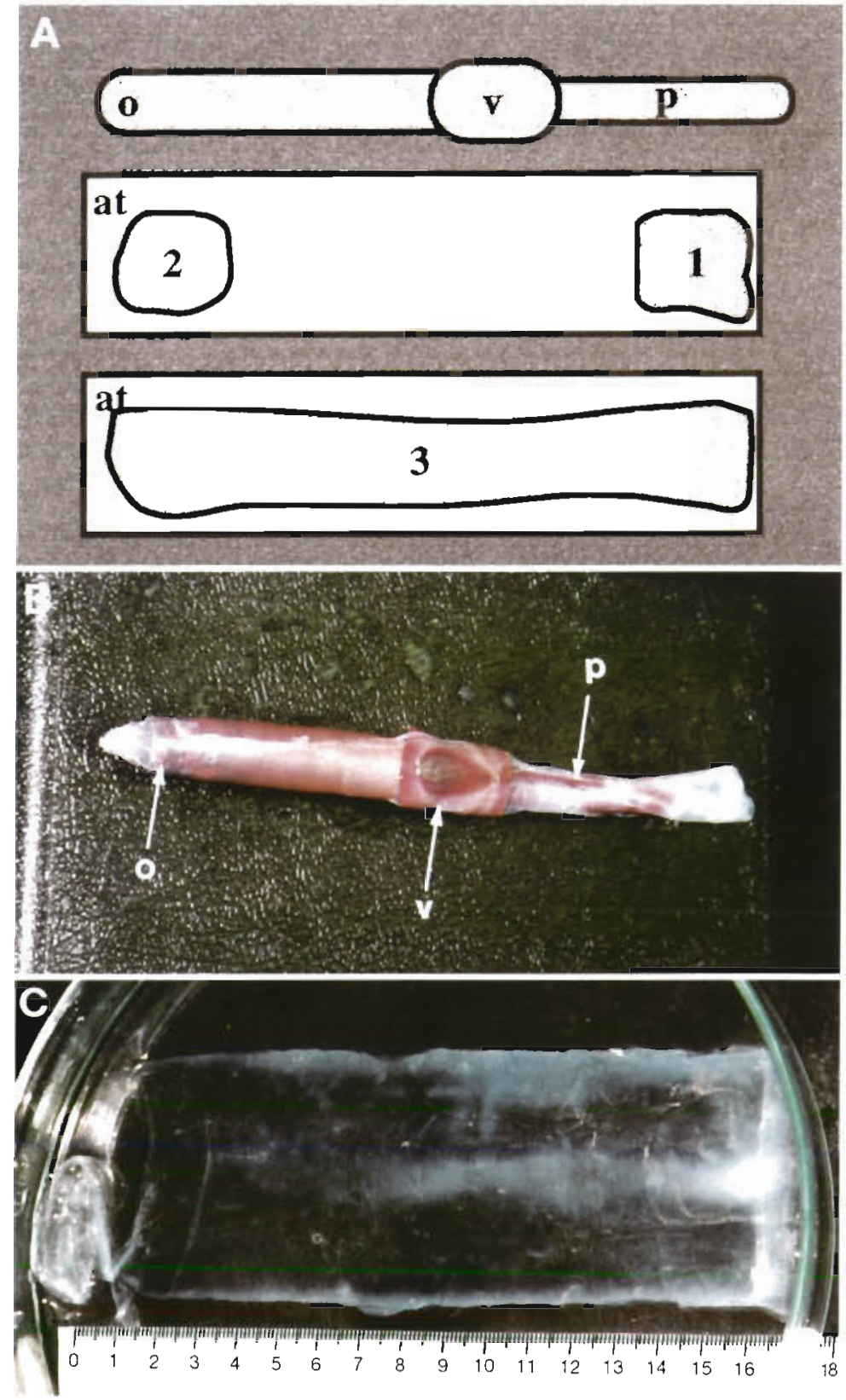

Fig. 1 (A) Riftia pachyptila. Illustration of the process of tube deposition over the artificial tube (at), depicted here flattened out after having been unwrapped from around the worms. Deposition starts at both the apical (1) and basal (2) extremities, corresponding to the main tube secretory regions, i.e. the vestimentum (v) and the opisthosome (o). The plume (p) has no tube secretory activity (Gardiner \& Jones 1993). Over longer time periods, deposition occurs over the entire surface of the artificial tube. (B) Photograph of a worm that was conditioned in an artificial tube, after the tube has been withdrawn. This animal was maintained $72 \mathrm{~h}$ in the pressure aquarium, and decompressed twice for maintainance reasons. It is entirely surrounded by its own fresh tube material, which appears slightle opaque. p: plume; v: vestimentum; $D$ : opisthosome. (C) Photograph of the fresh tube material produced by the worm in (B), after it has been cut open and flattened out (as illustrated in $A, 3$ ), showing that this material forms a single envelope around the worm. Scale units are $\mathrm{cm}$ 
tion was witnessed in some cases as soon as $3 \mathrm{~h}$ after repressurization. The 2 worms that seemed not to have produced any material were the smallest individuals (length $<5 \mathrm{~cm}$, weight $<2 \mathrm{~g}$ ). One other worm was dead at the end of the experiment and therefore disregarded, although it had laid down fresh tube material. Finally, 5 worms either underwent decompression during the experiment (mainly for reasons irrelevant to this work), or were used for other purposes (biochemical analyses): their fresh deposits were nevertheless used in this work for qualitative illustration of tube growth (Fig. 1). Therefore, 14 worms, originating from 4 different sites $\left(13^{\circ} \mathrm{N}\right.$ : Parigo [10], Genesis [2], $9^{\circ} \mathrm{N}$ : Riftia Field [1], $Q$-Vent [1]) were used for measuring production rates as a function of animal size (Fig. 2).

Over short time periods, as early as after $3 \mathrm{~h}$, qualitative observations show distinctly that tube deposition on the artificial tube starts at the apical and basal regions (as illustrated in Fig. 1). In terms of apparent quantity, the basal contribution seemed to be equivalent to the apical one. The fresh tube deposit forms a translucid film, which adheres to the artificial tube and is consistent enough to be sampled as a whole by 'peeling' it off the artificial tube, holding it with a pair of forceps. Over longer time periods, the apical and basal secretions join to form a single envelope. Such complete envelopes were observed as soon as $24 \mathrm{~h}$ after re-pressurization. The envelope displayed in Fig. 1 corresponds to a $3 \mathrm{~d}$ experiment.

The results displayed in Fig. 2 relate to tubeworms (14) that were not decompressed in the course of the experiment. Amongst these, worms from Parigo $13^{\circ} \mathrm{N}$

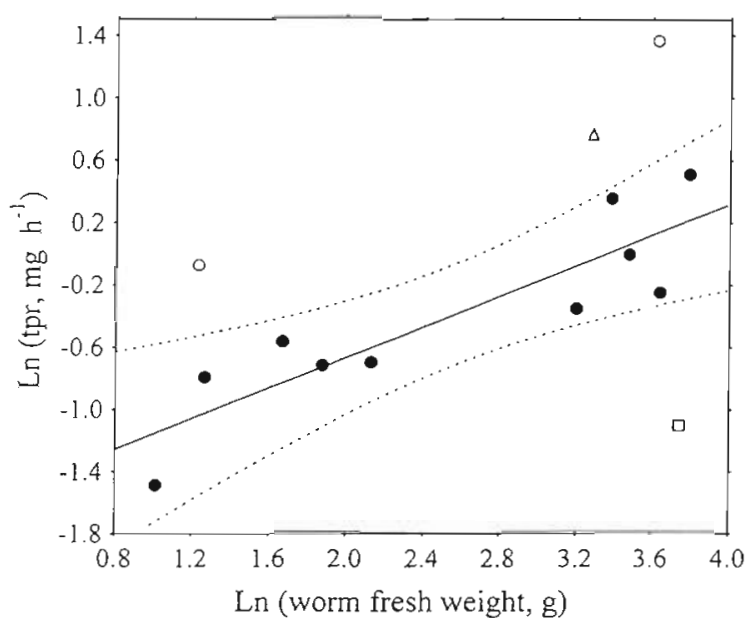

Fig 2. Riftia pachyptila. Log-transformed plot of fresh tube production rates (tpr, based on dry weights) versus individual fresh weight (ranging from 2.75 to $44.35 \mathrm{~g}$ ), for a group of 14 worms. All worms were submitted to an artificial environment similar to vent conditions and maintained for periods ranging from 3 to $26.5 \mathrm{~h}$ (average time $=17.0 \mathrm{~h}, \mathrm{SD}=7.0 \mathrm{~h}$ ). For Parigo $\left(13^{\circ} \mathrm{N}\right)$ worms (๑), tpr is correlated to individual weight following the equation $\ln y=0.492 \ln x-1.648(n=10, r=0.8849, p<0.001)$. When worms from other origins are considered, the corresponding values result in plots which are distinctly outside the $99 \%$ confidence area defined around the Parigo-worm slope.

(O) Genesis $\left(13^{\circ} \mathrm{N}\right)$; $(\Delta) \mathrm{Q}$-Vent $\left(9^{\circ} \mathrm{N}\right)$; ( $\square$ ) Riftia Field $\left(9^{\circ} \mathrm{N}\right)$

(Fig. 2) were collected during 3 different dives, and therefore were the object of 3 re-pressurization experiments, corresponding to 6 different durations of experiment (several vessels were available for each experiment, see Table 1). When animals originating

Table 1. Comparative display of experimental data concerning the individuals that are shown in Fig. 2. The weight error of dry tube material is $\pm 1 \mathrm{mg}$ and is accounted for in tube production rates (far right-hand column). Individuals are ranked according to increasing fresh weight from top to bottom, values in long horizontal boxes corresponding to sites other than Parigo. Boxes in tube production rate column allow for a comparison of the individuals of similar fresh weight (third column), but originating from different sites (first column)

\begin{tabular}{|lcccr|}
\hline Origin & $\begin{array}{c}\text { Duration of } \\
\text { experiment }(\mathrm{h})\end{array}$ & $\begin{array}{c}\text { Worm fresh } \\
\text { weight }(\mathrm{g})\end{array}$ & $\begin{array}{c}\text { New tube material } \\
\text { (mg, dry weight) }\end{array}$ & $\begin{array}{r}\text { Tube production rate } \\
\left(\mu \mathrm{g} \mathrm{h} \mathrm{h}^{-1} \mathrm{~g}^{-1} \text { worm }\right)\end{array}$ \\
\hline Parigo $\left(13^{\circ} \mathrm{N}\right)$ & 26.5 & 2.75 & 6 & $82 \pm 14$ \\
\hline Genesis $\left(13^{\circ} \mathrm{N}\right)$ & 15 & 3.50 & 14 & $266 \pm 19$ \\
\hline Parigo $\left(13^{\circ} \mathrm{N}\right)$ & 26.5 & 3.60 & 12 & $126 \pm 11$ \\
Parigo $\left(13^{\circ} \mathrm{N}\right)$ & 7 & 5.30 & 4 & $108 \pm 27$ \\
Parigo $\left(13^{\circ} \mathrm{N}\right)$ & 26.5 & 6.50 & 13 & $75 \pm 6$ \\
Parigo $\left(13^{\circ} \mathrm{N}\right)$ & 6 & 8.40 & 3 & $60 \pm 20$ \\
Parigo $\left(13^{\circ} \mathrm{N}\right)$ & 17 & 24.50 & 12 & $29 \pm 3$ \\
\hline Q-Vent $\left(9^{\circ} \mathrm{N}\right)$ & 24 & 26.50 & 52 & $82 \pm 2$ \\
\hline Parigo $\left(13^{\circ} \mathrm{N}\right)$ & 7 & 29.40 & 10 & $49 \pm 5$ \\
\hline Parigo $\left(13^{\circ} \mathrm{N}\right)$ & 17 & 32.40 & 59 & $31 \pm \overline{2}$ \\
\hline Genesis $\left(13^{\circ} \mathrm{N}\right)$ & 15 & 37.50 & 18 & $105 \pm 2$ \\
\hline Parigo $\left(13^{\circ} \mathrm{N}\right)$ & 23 & 38.20 & 8 & $21 \pm 1$ \\
\hline Riftia Field $\left(9^{\circ} \mathrm{N}\right)$ & 24 & 41.90 & 5 & $8 \pm 1$ \\
\hline Parigo $\left(13^{\circ} \mathrm{N}\right)$ & 3 & 44.35 & $38 \pm 8$ \\
\hline
\end{tabular}


from Parigo are considered, the tube production rates throughout the experiment $(y)$ correlate to the fresh weight of animals $(x)$, following an almost square-root relationship $\left(y=0.192 x^{0492} ; \mathrm{n}=10 ; \mathrm{r}=0.8849 ; \mathrm{p}<\right.$ 0.001 ) (Fig. 2). This shows that smaller worms produce relatively more tube material than larger ones (see also Table 1). Another observation is that this correlation exists despite variations in the length of experiments, which ranged from 3 to $26.5 \mathrm{~h}$.

When worms originating from other sites are considered, the corresponding values result in data points (Fig. 2) that are far outside the $99 \%$ confidence interval defined for the Parigo worms. Table 1 allows for a comparison of production data for similar-sized individuals (production rates given in the last column of Table 1). It shows that the 2 individuals from Genesis produced at least twice as much fresh tube material than their Parigo equivalents.

Lastly, carbon content of the new tube material was $18.26 \pm 5.86 \%(\mathrm{SD})$.

Discussion. One of the goals of this study was to quantify the process of tube synthesis in the case of Riftia pachyptila, first because it is one of the most important sources of biomass in the vent ecosystem (Tunnicliffe 1991), and second because deep-sea vent production data are scarce at the present time, despite significant knowledge concerning the trophic structures of these ecosystems (Van Dover 1995).

In this work the presence of fresh deposits in the basal and apical regions, and later over the entire surface of the artificial tubes, confirms that tube synthesis is not only devoted to apical elongation. Our results show that the opisthosome region is an important tubeproducing area, which is either used for constructing basal partitions inside the tube, or for construction of basal extensions of the tube, as suggested in previous work (Gaill et al. 1997). The case of Riftia pachyptila is in contrast to other vestimentiferan species, for which apical elongation seems to be the main contributor to tube growth (Fisher et al. 1996).

Tube growth may be considered in terms of carbon production, either at the individual physiological level, or at the more ecological level of a population of tubeworms. For the Parigo worms, and with a $18.26 \%$ carbon content, this corresponds to production rates ranging from 0.32 to $1.92 \mu \mathrm{MC} \mathrm{h}^{-1} \mathrm{~g}^{-1}$ worm. The 2 Genesis worms reach 1.59 and $4.05 \mu \mathrm{M} \mathrm{Ch}^{-1} \mathrm{~g}^{-1}$ worm, this last value being for the smallest worm ( $3.5 \mathrm{~g}$ fresh weight). A comparison of the maximum rate of carbon fixation observed in this species $\left(2.74 \mu \mathrm{M} \mathrm{CO}_{2} \mathrm{~h}^{-1} \mathrm{~g}^{-1}\right.$ worm, Childress et al. 1991$)$ at a similar temperature $\left(13.5^{\circ} \mathrm{C}\right.$, as opposed to $15^{\circ} \mathrm{C}$ in this study) indicates that tube growth is a major component of the carbon production budget. This is not surprising, considering the multiple roles of the tube, which not only acts as protection against predation, and presumably against temperature variations, but also acts as a stalk, thus allowing optimal positioning of the plume to allow access to vent fluid (Gaill et al. 1997), in an environment where competition for space is important (Hessler et al. 1985). However, we cannot rule out the possibility that the observed daily rates are the result of stress-induced hyperactivity in tube growth. Indeed, it is likely that the collection process would induce such stress, while it did not seem to have impaired the physiological potential of the experimental individuals (as suggested by the present work) once environmental conditions closer to those prevailing in the native habitat were restored (i.e. in the pressure vessels). It may therefore be that the observed rates reflect 'maximum potential rates' rather than 'normal' in situ rates.

In densely packed clusters of Riftia pachyptila, maximum densities have been estimated to be in the range of 200 ind. $\mathrm{m}^{-2}$ or more (Fustec et al. 1987, 1988, review in Tunnicliffe 1991, Sarradin et al. 1998). The average weight of individuals in such clumps was estimated to be $250 \mathrm{~g}$ (Fustec et al. 1988), a much larger size than the biggest animal at our Parigo site study, i.e. $44.35 \mathrm{~g}$ for $28 \mathrm{~cm}$ total length. Therefore, the closest estimation we are able to provide would be for a cluster of worms (200 ind. $\mathrm{m}^{-2}$ ) for which the weight would be at the upper limit of those weights found in our study, i.e. $44.35 \mathrm{~g}$ (Fig. 2, Parigo worms, and Table 1). In accordance with this, a tube production of $5.97 \mathrm{~g} \mathrm{~m}^{-2} \mathrm{~d}^{-1}$ is obtained by using the equation provided by the results of Fig. $2\left(y=0.192 x^{0.492}\right)$. Based on carbon content analysis, it yields a carbon production of over $1 \mathrm{~g} \mathrm{C} \mathrm{m}^{-2}$ $\mathrm{d}^{-1}$ (1.09) for a clump of worms behaving as those studied in this work. Tentatively, extrapolation to $1 \mathrm{yr}$ leads to a gross tube production of $2.18 \mathrm{~kg} \mathrm{~m}^{-2} \mathrm{yr}^{-1}$ (dry weight), meaning a carbon production of about $398 \mathrm{~g} \mathrm{C} \mathrm{m}^{-2} \mathrm{yr}^{-1}$. To the extent that such a 1 yr extrapolation is possible, it must be stressed that total production of such a clump of tubeworms would certainly be higher, first because the growth of the actual organism is not accounted for in this work, and second because our estimation is based on a $44 \mathrm{~g}$ average weight, which is likely to be smaller than the actual average animal size, as suggested above (Fustec et al. 1988). Yet, these results are readily comparable to values encountered for highly productive benthic species, such as coastal mussel beds (about $5 \mathrm{~kg} \mathrm{~m}^{-2} \mathrm{yr}^{-1}$ dry weight, Abada-Boudjema \& Dauvin 1997), or crustaceans occurring in debris-accumulating submarine canyons (3.3 $\mathrm{kg} \mathrm{m}^{-2} \mathrm{yr}^{-1}$ dry weight, vetter 1994).

It is possible that the quantities produced in vitrosurpass the actual in situ daily productions, as discussed above. However, the observed coherence of the in vitro production rates of the experimental Parigo worms (Fig. 2) and a comparison with experimental worms 
from other sites strongly suggest that these data reflect at least qualitatively in situ behaviour. Moreover, it seems that this site-related behaviour persists at least for $1 \mathrm{~d}(26.5 \mathrm{~h}$ is the longest experimental time period included in Fig. 2), meaning that these worms keep a 'physiological memory' of their site of origin that has not yet been erased by the identical artificial environment experienced in the pressure vessels. Sitedependent physiology has been demonstrated in several studies (Childress et al, 1993, Gorodezky \& Childress 1994), and particularly in recent work from Goffredi et al. (1997), which shows that the inorganic carbon content of freshly collected worms depends significantly on site of origin. It is not, therefore, surprising that the presently studied tubeworms originating from different sites still show some differences in their tube production rates several hours after they have been withdrawn from their environment, despite identical chemical conditions in the vessels; indeed, tube production may be considered as a late step in the Riftia pachyptila-symbiont carbon transfer chain, as opposed to carbon uptake, the first process. Therefore, it probably takes longer for tube synthesis to be affected by environmental changes (the conditions imposed in the pressure vessels) than it does for inorganic carbon uptake. How long these production rates would be maintained over longer time periods, and which environmental factors are involved, remains to be determined. Further experiments will aim at investigating these aspects during future survey cruises, bearing in mind that such tube production experiments could provide valuable biological information about the evolution of the vent sites themselves.

Acknowledgements. We thank N. Desaulniers, S. Goffredi, R. Chambert, M. Zbinden, the Nautile Group (IFREMER), the master and crew of the ships 'Nadir' and RV 'Wecoma', for their help throughout this work. We are also grateful to A. Khripounoff, from the DRO/EP Dpt (IFREMER/ Brest) for instrumental facilities. This work was funded by CNRS, INSU, IFREMER, DRET (509647), NSF (OCE9632861), and EC (DG XII) grants.

\section{LITERATURE CITED}

Abada-Boudjema YM, Dauvin JC (1997) Cinetique et production de deux moulieres naturelles de l'est Algerois. Influence des facteurs thermiques et anthropiques. Oceanol. Acta 20:229-241

Childress JJ, Fisher CR (1992) The biology of hydrothermal vent animals: physiology, biochemistry and autotrophic symbioses. Oceanogr Mar Biol Annu Rev 30:337-441

Childress JJ, Mickel TJ (1980) A motion compensated shipboard precision balance system. Deep-Sea Res 27 A:965-970

Editorial responsibility: Otto Kinne (Editor),

Oldendorf/Luhe, Germany
Childress JJ, Fisher CR, Favuzzi JA, Kochevar RE, Sanders NK, Alayse AM (1991) Sulfide-driven autotrophic balance in the bacterial symbiont-containing hydrothermal vent tubeworm, Riftia pachyptila Jones. Biol Bull 180:135-153

Childress JJ, Lee RW, Sanders NK, Felbeck H, Oros DR, Toulmond $A$, Desbruyères $D$, Kennicutt $M C$, Brooks J (1993) Inorganic carbon uptake in hydrothermal vent tubeworms facilitated by high environmental $\mathrm{pCO}_{2}$. Nature 362:147-149

Fisher C, Urcuyo l, Simpkins M, Nix E (1996) Life in the slow lane: growth and longevity of cold-seep vestimentiferans. Mar Biol 18:83-94

Fustec A, Desbruyères D, Juniper SK (1987) Deep-Sea hydrothermal vent communities at $13^{\circ} \mathrm{N}$ on the East Pacific Rise: microdistribution and temporal variations. Biol Oceanogr $4: 121-164$

Fustec A, Desbruyères D, Laubier L (1988) Estimation de la biomasse des peuplements associés aux sources hydrothermales profondes de la dorsale du Pacifique oriental, à $13^{\circ} \mathrm{N}$. Oceanol Acta 8:15-22

Gaill F, Hunt S (1986) Tubes of deep sea hydrothermal vent worms Riftia pachyptila (Vestimentifera) and Alvinella pompejana (Annelida). Mar Ecol Prog Ser 34:267-274

Gaill F, Shillito B, Menard F, Goffinet G, Childress JJ (1997) Rate and process of tube production by the deep-sea hydrothermal vent tubeworm Riftia pachyptila. Mar Ecol Prog Ser 148:135-143

Gardiner SL, Jones ML (1993) Vestimentifera. In: Harrison FW, Rice ME (eds) Microscopic anatomy of invertebrates, Vol 12. Wiley-Liss Inc, New York, p 371-460

Goffredi S, Childress JJ, Desaulnier $N$, Lee $R_{1}$ Lallier F, Hammond D (1997) Inorganic carbon acquisition by the hydrothermal vent tubeworm Riftia pachyptila depends upon high external $\mathrm{PCO}_{2}$ and upon proton-equivalent ion transport by the worm. J Exp Biol 200(5):883-896

Gorodezky LA, Childress JJ (1994) Effects of sulfide exposure history and hemolymph thiosulfate on oxygen-consumption rates and regulation in the hydrothermal vent crab Bythograea thermydron. Mar Biol 120:123-131

Hessler RR, Smithey WM, Keller CH (1985) Spatial and temporal variation of giant clams, tube worms and mussels at deep-sea hydrothermal vents. Biol Soc Wash Bull 6:411-428

Lutz R, Shank T, Fornari D, Haymon R, Lilley M, Von Damm K, Desbruyères D (1994) Rapid growth at the deep-sea vents. Nature 371:663-664

Roux M, Rio M, Schein E, Lutz E, Fritz LW, Ragone LM (1989) Mesures in situ de la croissance des bivalves et des vestimentifères et de la corrosion des coquilles au site hydrothermal de $13^{\circ} \mathrm{N}$ (dorsale du Pacifique oriental). C R Acad Sci 308:121-127

Sarradin PM, Caprais JC, Briand P, Gaill F, Shillito B, Desbruyères $D$ (1998) Chemical and thermal description of the environment of the Genesis hydrothermal vent community (130 N, EPR). Cah Biol Mar 39:159-167

Tunnicliffe $V$ (1991) The biology of hydrothermal vents: ecology and evolution. Oceanogr Mar Biol Annu Rev 29: 319-417

Van Dover CL (1995) Ecology of mid-Atlantic Ridge hydrothermal vents. In: Parson LM, Walker CL, Dixon DR (eds) Hydrothermal vents and processes, Vol 87. London Geological Society, London, p 257-294

Vetter EW (1994) Hotspots of benthic production. Nature $372: 47$

Submitted: September 7, 1998; Accepted: March 29, 1999

Proofs received from author(s): June 4, 1999 